\title{
South Africa's Call Centre Industry: The Emerging Challenges of a Growing Destination in the Global South
}

\author{
Wayde R. Pandy \\ Christian M. Rogerson
}

School of Tourism \& Hospitality, Faculty of Management, University of Johannesburg, South Africa

Corresponding author: crogerson@uj.ac.za

\section{Doi:10.5901/mjss.2014.v5n8p208}

\begin{abstract}
Call centres are one of the largest sectors of business process outsourcing and offshoring, which has expanded into a major activity in the global South. Over the past 15 years much government attention has been accorded in South Africa to promoting the country as a destination location for call centres in support of job creation particularly for unemployed youth. This article critically analyses the trajectory of call centre development, policy evolution and business development challenges in South Africa. It is revealed that South Africa is seeking to maximise the role of impact sourcing for employment. Critical issues remain around restructuring the location of call centres which are strongly concentrated in the most economically developed parts of the country.
\end{abstract}

Keywords: BPO \& 0; offshoring; call centres; South Africa; impact sourcing; locational issues

\section{Introduction}

Enterprises are increasingly sourcing their business processes through external service providers, a practice which is styled as Business Processing Outsourcing (BPO). In an increasingly globalized world the activity of business process outsourcing (BPO) has become one of the most broadly adopted business strategies (Ghodswar \& Vaidyanathan, 2008; Lacity \& Wilcocks, 2013). The terminology of business process outsourcing and offshoring refers to the practice whereby a company identifies and breaks down its business-related activities into a series of basic processes, and then outsources those processes that are not seen as the most important or core to the company's survival. Historically, whilst such developments initially saw the outsourcing of non-essential service activities to often deindustrialized regions within the same country, recent global trends have witnessed a high percentage of business processes outsourced and sent offshore to countries in the global South where available cheap labour can reduce operational costs. The offshoring of BPO is inseparable from broader processes of globalization whereby labour-intensive activities have increasingly shifted from countries in the global North, to the global South where labour is considered relatively cheaper and more widely available (Vira \& James, 2011). Among others Aziz (2013) points out that intense competitive pressures to reduce costs between multinational enterprises has prompted a host of organisations to offshore and relocate their non-core operations to low cost destinations, such as India and the Philippines

At the broadest level of classification, areas of services in the BPO \& O sector can be separated into two distinct groups. On the one hand are back office operations, the activities of which involve business processing functions such as finance and administration, and on the other hand are front office operations which relate mainly to business operations involving customer interactive services, that see direct contact between firm operators and customers (Penter et al, 2009). In terms of job creation, it is recognized that front office operations, which mostly involve customer interaction over the telephone, are the most dominant and sought after services in the BPO \& O sector. In recent years BPO \& $O$ (Business Processing Outsourcing and Offshoring) has become acknowledged as one of the fastest growing global economic phenomenon. Lau \& Zang, 2006 and Kaka et al, (2006) estimate \$154 billion for the size of the industry. But, according to Lacity et al (2011) the contemporary BPO market could be worth globally as much as $\$ 279$ billion with projections of annual growth of 25 percent.

The rise of BPO \& $O$ activities on the global scale has attracted a growing body of international research, particularly over the past 15 years. Among key issues under scrutiny have been issues about decision-making in relation to motivations for outsourcing or client firm characteristics and studies around outcomes in relation to for example country 
characteristics or supplier capabilities (Lacity et al. 2011). Business scholarship on this phenomenon continues to expand with recent investigations targeted at inter alia, entry strategies (Luo \& Jayaraman, 2013), human resource issues (Kuruvilla \& Ranganathan, 2010; Thaly \& Sinha, 2013), partnership qualities (Ee et al 2013) and critical debates around innovation (Lacity \& Willcocks, 2013). Beyond business scholars, the activity of BPO \& O has been of particular concern to a number of governments in the global South because of its potential economic and investment benefits and in particular for the sector's proven ability to aid in employment creation. The leading competitive destinations for the offshoring of BPO in the global South are India and the Philippines. Other countries are seeking to capture part of the growing BP \& O economy, including in sub-Saharan Africa where Kenya (Waema et al. 2009) and South Africa (Banks \& Roodt, 2011; Nelson Hall, 2011; Pandy \& Rogerson, 2012) are the most prominent players. It is the challenges of industry development in one growing destination for BPO \& O in the global South that are the focus in this article.

\section{Aims, Structure and Research Methods}

Within sub-Saharan Africa the most established sector of BPO is found in South Africa. Indeed, the specific South African case since the early 2000s is distinguished by the growth of a range of government interventions and initiatives in support of expanding the competitiveness of the country for the offshoring of BPO work. The critical imperative for national government seeking to build the competitiveness of the country's BPO \& O economy concerns high levels of national unemployment, estimated to be at least 27 percent, and of the even worse problem of youth unemployment. Against this backdrop of the mounting significance of what is locally described as the Business Process Outsourcing and Offshoring (BPO \& O) sector, the aim in this paper is to critically analyse the trajectory of its development, policy evolution and business development issues. More specifically, the call centre industry is under scrutiny as the leading edge example of the growing phenomenon of BPO \& O in South Africa.

Structurally, the paper unfolds by briefly first identifying the key aspects of scholarship around call or contact centres as an illustration of BPO \& O. Next the rise in significance of BPO \& $O$ in South Africa and the key issues facing and challenging the growth of BPO \& $\mathrm{O}$ in South Africa are tracked through a detailed investigation of the call centre industry. The role of government interventions in shaping the growth and directions of South Africa's call centre industry is profiled, focusing especially on supporting job creation for the youth. Finally, the particular challenges that confront the achievement of national government objectives are highlighted in respect of restructuring the existing geographical patterns of call centre location.

Methodologically, the paper builds upon an analysis of industry reports and government policy documents. In addition, in terms of examining locational issues the findings draw upon the development of a national spatial data base on call centres and from a total of 42 interviews that were undertaken with a purposive sample of call centre operations across South Africa. The survey sought to investigate the key decision-making factors that impact upon the location of call centres.

\section{Literature Review}

The integration of information and computer technologies has been central to the growth of call centres for it has facilitated the optimization of service delivery to customers (Taylor \& Bain, 1999). It is argued that call centres, sometimes styled also as 'customer service facilities' or 'contact centres', "have become an increasingly important part of the business landscape in many countries" (Bishop et al. 2003, p. 2751). Indeed, Banks and Roodt (2011, p. 3) can assert that "in today's business world, call centres are an inevitable component of service delivery". Correspondingly, it is clear that "call centres have moved from occupying a relatively small niche to being a significant part of the global economy" (Banks \& Roodt, 2011, p. 3)

Internationally, however, call centres are not a homogeneous phenomenon. A basic service-oriented distinction must be made between customer care, involving the taking of inbound calls, offering technical support, taking reservations or fielding information queries, and the activity of telemarketing (cold selling) which focuses on making outbound calls (Vincent \& McKeown 2008). In certain call centres both these functions are combined in various ways. The varying nature of call centre work impacts enormously upon the levels of skills required and correspondingly upon the quality of work. Organizationally, call centres are further differentiated between in-house operations which emerge within existing firms and of independent outsourcing organisations which may offer specialised or more general services. Often these latter centres perform routinized functions and are staffed by relatively low skilled personnel. This said, a small number of these centres offer highly specialised technical advice, for example on medical or IT issues (Bishop et al. 2003). With the advance of globalization further differentiation has occurred in respect of the nature of call centres. 
Specifically, the (re) location of call centres outside the home country has precipitated the expanding phenomenon of the international or offshore contact centre. This offshore call centre is an integral element of the wider expanding global business service sector or of business process outsourcing and offshoring (BPO \& O) activities. Distinctions are drawn between 'captive' operations (wholly owned subsidiaries) and independent or 'third party' outsourced contractors (Agrawal et al., 2010; Sass \& Fifekova, 2011). Arguably, therefore, call centres must be understood as "heterogenous organisations taking a variety of forms and offering different types of service" (Bishop et al., 2003, p. 2754).

International scholarship around call centres has burgeoned over the past two decades. Contributions have emerged from a range of disciplinary viewpoints including management science, urban studies, organisation studies, sociology and human geography (Paulet 2004; Vira \& James, 2011). It is observed that the phenomenon of call centres "has been tackled from many dimensions and perspectives in an attempt to explain this relatively new and different part of the world of work and employment" (Paulet 2008, p. 306). A number of issues have been scrutinised with research across a range of countries and contexts with the Indian experience among the best documented in recent writings (see Ramesh, 2004; Penter et al. 2009; Agrawal et al. 2010; Kuruvilla \& Ranganathan, 2010; Mishra, 2011; Vira \& James, 2011; Suchet, 2012; Valdyanathan, 2012; Aziz, 2013; Ghosh, 2013; Taylor et al. 2013).

Labour and management studies give central attention to the 'internal workings' of call centres and to questions of management control, labour processes and worker surveillance which are associated with the ICTs that are integral to call centre operations (Taylor et al., 2009, 2013). Arguably, the call centre is "pivotal to tightening the control over the labour process, to intensifying work and transforming the experience of work" (Ellis \& Taylor 2006: 107). In one Spanish investigation the intensive application of performance monitoring systems prompted the descriptive analogy of "the bird cage model of call centre work"(Marti-Audi et al., 2013). Because of its often stressful work conditions and limited career growth prospects, the nature of call centre work has prompted the use of other descriptors, including 'cyber coolies', 'electronic sweatshops', 'assembly lines in the head' and 'dark satanic mills', (Taylor \& Bain, 1999; Benner, 2006; Suchet, 2012). In one recent Australian investigation it was highlighted that call centre workers encounter major psychological pressures, including high work intensity and undesirable working hours (Bohle et al., 2011). The impact of stress on worker burnout and retention has been further articulated in New Zealand (Rod \& Ashill, 2012). Questions about the factors that cause stress have come under investigation also for call centres in India (Aziz, 2013) Overall, it is emphasized that whilst call centres can generate much needed job opportunities, often they are criticised "as a low paying and undesirable form of work, which are reliant upon factory style and Taylorist production methods" (Hastings, 2011, p. 98).

Issues around the quality of work, human resource management policies, and labour processes in call centres continue to attract scholarly attention both nationally and in the transnational dimension (Ellis \& Taylor, 2006; Hannif et al., 2008; Banks \& Roodt, 2011). Valdyananathan (2012) analyses how the notion of 'professionalism' is understood from below by employees and the potential for mobilization by trade unions in Indian call centres. The influence of call centres upon changing the lives and identities of young workers is a further investigatory issue. In Indian research Ghosh (2013) traces the gender and work transformations of call centre workers in Bangalore. From a further Bangalore-based study Mishra (2011) unpacks the impacts of call centres upon young women subjected to the experiences of a western world in a global milieu in both real and virtual ways.

Another important sub-theme of investigation on call centres, both at the national and international scale of analysis relates to location decision-making and the factors impacting upon the actual choice for establishing a call centre in a particular locality or space. At the international scale of decision making Taylor \& Bain (2005, p. 264) argue that the locational calculus for the call centre industry must be understood not as the product of corporate desire to improve customer service but primarily as the consequence of "the massive cost reduction consequent upon the centralization of previously dispersed customer service and sales operations". In a seminal analysis, Bishop et al (2003, p. 2754) point out that call centres offer organisations "the opportunity to achieve economies of scale through centralising service provision in fewer locations and closing traditional outlets". Accordingly, it is argued ultimately customer interests are "subordinated to the imperatives of capital accumulation and profit maximisation" (Taylor \& Bain, 2005, p. 264). In this regard the decision of where to locate call centres is inseparable from the interrelated objectives of cost minimization and profit maximisation which need to be set against issues of quality of service provision (Paulet 2008). Beyond the macro-scale of location decision making, another stream of studies have interrogated the shifting geographies of call centres within countries and within particular urban regions. The attractiveness of call centres as vehicles for local development in the context of post-industrial economies has attracted several studies (Richardson \& Marshall, 1996; Richardson et al., 2000; Richardson \& Bell, 2001; Bishop et al., 2003; Rowthorn, 2010). As is elaborated below locational issues can be of vital policy relevance also in a developing world context such as South Africa. 


\section{The Call Centre Industry in South Africa}

In recent years, the BPO \& O sector involving call centres has become a major focus of government attention in South Africa (DTI, 2005; DTI, Business Trust \& Business Process Enabling South Africa, 2009; DTI, 2013). The South African government has acknowledged the potential benefits that the development of a competitive and sustainable BPO \& $O$ call centre environment could produce. It has been suggested that if an appropriate policy environment were established and effective actions implemented that additional employment opportunities for 100, 000 (25000 direct employment and 75000 indirect employment) workers could be attained over the next four years (Rogan et al., 2013).

At the core of government planning is the attraction of expanded global offshoring operations. It is estimated that global operations in this sector in the country currently support approximately 14000 jobs; national government's short to medium term goal is to expand this to 40000 employment opportunities by 2015. (DTI, 2013: 108). Of particular significance in South Africa is the potential contribution of call centres for addressing the segment of youth unemployment, which currently stands at an estimated 50 percent. In particular, much policy attention surrounds the possibility of boosting what is locally styled as "impact sourcing" (Rogan et al., 2013). The concept of impact sourcing refers to the employment of people who are most disadvantaged, with limited alternative opportunities for employment, and are to be the principal source of workers in business process outsourcing centres either for domestic in house operations but most importantly for helping the servicing of international clients, ie offshoring.

Table 1: The Growth in Call Centre Operations in South Africa

\begin{tabular}{|c|c|}
\hline Year & Estimated Number of Centres \\
\hline 1997 & 185 \\
\hline 2002 & 535 \\
\hline 2004 & 653 \\
\hline $2007 / 8$ & 1342 \\
\hline 2012 & 1500 \\
\hline
\end{tabular}

Source: Industry reports

Although the precise origins of South Africa's first established call centres cannot be confirmed, the consensus is that during the 1970s a number of local firms were performing tasks and functions that by current standards, definitions and criteria would conform to what are now referred to as 'call centres'. For example, in Cape Town, it is recorded the first call centres were initiated in the mid-1980s to service companies with a high customer contact requirement in the financial services industry (Pandy \& Rogerson, 2012). Further growth of the industry nationally commenced in the early 1990s (Benner, 2006) and accelerated after democratic transition in 1994. Nevertheless, it was only in the late 1990s that the combination of improved computer technology and reduced telecommunication costs contributed to a rapid expansion of call centres. (Benner et al., 2007: 10). Table 1 triangulates several industry sources to chart the expansion in the number of call centres in South Africa. It reveals the surge in call centre operations particularly after 2004 and with a further upturn post-2007 which is linked to a series of government interventions, including the launch of incentive programmes, to boost the competitiveness of South Africa for the establishment of offshore call centres (DTI, 2008a, 2008b). In terms of international destinations for offshore call centre operations South Africa is usually considered to be in competition with in particular Poland, India and the Philippines.

Overall, it is crucial to appreciate that as compared to other destinations in the global South the development trajectory of South Africa's call centre industry has taken a markedly different course. In the much profiled cases of India and Philippines, the call centre industry emerged as part of broader international offshoring of business services directly (Rodolfo, 2006; Taylor et al., 2009). By contrast the South African call centre industry has historically evolved to service the country's domestic market (Benner, 2006). In a 2004 industry investigation it was revealed the largest proportion of call centres in South Africa serviced local companies and their customers (Paladin Consulting and Consulta Research, 2004). Moreover, the industry continues to be overwhelmingly dominated by firms which service only the domestic market (C3 Africa 2008). As argued by Banks and Roodt (2011, p.3) "South Africa was largely a captive environment where organisations own the centre and use it exclusively for their own purpose". The greatest proportion of such centres are operations that link to local domestic banking, insurance, other financial services, the health sector, travel and hospitality, and telecommunications (Benner et al. 2007).

From our research and that of a number of recent industry investigations, the key dimensions of call centres in 
contemporary South Africa can be understood (C3 Africa Research 2008; Pandy \& Rogerson, 2012; Rogan et al., 2013). The two essential services are on the one hand international contact centre services and voice and non-voice support for the domestic South African market. Overall, as Rogan et al (2013) show about the business process service sector as a whole South Africa mainly offers contact and call centre services with an estimated 70 percent of international BPO service delivery related to call centres. Arguably the sector has matured as many of its call centres which were formally only voice calls are now contact centres to the extent that they seek to offer various transactional services beyond inbound and outbound phone voice call services. Inbound customer service represents the basis of over two-thirds of South African call centre operations and whilst marketing or sales activities are outsourced, inbound customer service is more usually captive. Importantly, the largest share of call centres are captive or in-house operations; the research disclosed almost two-thirds were captive operations. The country's call centres vary markedly in size from small establishments which employ only a handful of operators to larger operations which engage over 1000 agents. Most call centres are small and have less than 20 seats. Overall, it is shown the group of captive or in-house operations are much smaller in size as indexed by number of seats as compared to the group of outsourced contact centres (C3 Africa Research 2008). A national survey disclosed almost two-thirds of call centres had less than 50 seats and 48 percent less than 20 seats (C3 Africa Research 2008). This confirms earlier findings by Benner et al. (2007, p. 7) that the median size of call centre in South Africa was 24 employees, which is much smaller than international norms.

Of importance in restructuring the industry is the entry and expansion of offshore BPO \& O operations into South Africa especially since the early 2000s (Paladin Consulting and Consulta Research 2004). Benner et al (2007) reveal that the proportion of outsourced activity in South Africa's call centre industry is rising, estimating that as much as 9 percent of call centres in the country were serving primarily international markets in 2007. By 2013, this share is generally considered to have expanded (Rogan et al, 2013). The most recent estimates suggest that as many as 200000 people are currently employed directly or indirectly within the BPO \& O sector of the South African market (Rogan et al. 2013, p. 6). Among the list of prominent international companies which have established offshore operations in South Africa are Amazon, Barclays, British Gas, JP Morgan, Lufthansa, Microsoft, Shell and Virgin Mobile (Mochiko, 2013). In particular, the selection of Cape Town by Amazon and establishment of operations there in 2010 is considered an important landmark in the emergence of South Africa as an offshoring destination. As a whole in terms of clients, currently the majority of international firms originate either from the United Kingdom (56 percent) or the United States (17 percent). In addition, there is a notable interest from Australia in terms of allowing $24 / 7$ operations using a South African call centre to complement either an existing Australian or Philippines operations. The importance of United Kingdom, USA and most recently Australia as offshore source markets for South Africa is explained in terms of existing historical and cultural linkages, the availability of English language skills and the favourable time difference (Lacity et al., 2012; DTI, 2013).

As compared to competing destinations for offshoring such as India or the Philippines, South Africa does not seek to compete on the basis of labour and operational costs but instead in terms of the country's capacity to offer high levels of customer experience as well as the ability to handle complex processes. South Africa remains an inappropriate location for low end large-scale processing of simple transactions or customer queries when the quality of customer experience is not a core management consideration (Nelson Hall, 2011). In terms of government strategic planning it is asserted that "South Africa is increasingly competing to be among the most preferred destinations for international operators and enterprises, wherever located, that are looking for cost-effective destinations in which to locate their operations" (DTI, 2013: 108).

One recent investigation identified the core reasons for many international companies to select South Africa as an offshore destination for call centre operations (Nelson Hall, 2011). Several critical factors were highlighted.

- The issue of timezone compatibility with UK and Europe

- Cost savings of between 30 to 50 percent as compared to onshore delivery of services from UK or Australia

- High level of cultural affinity between South Africa and the UK, Europe and Australia.

- Availability of potential agents with language skills for servicing German and Dutch markets, the latter arising from the closeness of Afrikaans.

- The attitude of agents towards contact centre work and a so-termed 'natural' attitude towards customer service;

- The quality of contact centre agents that can be recruited in South Africa

- The high adaptability of the South African accent for clients in the UK, USA or Australia.

- Ease of management of South African operations as compared to other offshore locations.

- Lower levels of worker attrition as compared to onshore service delivery; and 
- The attractiveness of Cape Town as a destination for international managers to either visit or spend a period of worktime in relation to setting up and managing operations (Nelson Hall, 2011).

Overall, the emphasis for offshoring is the upon effectiveness and service delivery from South Africa as a call centre operation rather than absolute cost reduction because of labour cost considerations. As stressed by Lacity et al (2012). South Africa is attractive as a location to complement the global portfolios of many international companies with already established operations in Eastern Europe, India and Philippines. Indeed, it is asserted that "South Africa's value proposition cannot only be about costs because other locations are cheaper; South Africa's value proposition is about overall economic value, high quality staff, high cultural compatibility, and favourable time zone" (Lacity et al., 2012: 22).

Rogan et al (2013) maintain there is a substantial potential pool of talent and human capital to service the country's call centre industry as well as other aspects of business services. One recent investigation revealed that in terms of current industry staffing the majority of workers are aged under 35 years and have at least Grade 12 level of educational qualification. Moreover, the largest share of workers enjoy full time employment positions. An observed trend is for local in-house or captive firms to hire the older youth (ie age 26-30) whereas the outsourced call centres engage mainly 18 to 25 years. The racial employment profile of call centres reveals the growth in numbers of black agents and supervisors particularly in those call centres which service government (C3 Africa Research, 2008). Nevertheless, the national profile discloses black South Africans remain under-represented in the call centre industry, particularly in high level supervisory positions. It is estimated that whilst Blacks constitute 79 percent of national population, they represent only 27 percent of agents, 18 percent of team leaders and 7 percent of managers; by contrast whites, who constitute approximately 10 percent of South Africa's population currently are 26 percent of call agents, 37 percent of team leaders and 61 percent of managers.

\section{Government Intervention}

A vital role in growing and seeking to reshape the nature of the call centre industry in South Africa is played by national government. With the imperatives of high levels of structural unemployment that plague the post-apartheid economy, the BPO\& O sector was isolated as one of the 'priority sectors' for attracting investment, stimulating economic growth and creating job opportunities as part of South Africa's Accelerated Shared Growth Initiative (DTI 2005, 2011; DTI, Business Trust, \& Business Process Enabling South Africa 2009). The discourse around call centres in the mid-2000s was positive and suggested strong evidence existed of "the community-building potential" of this sector, its potential for catalysing small enterprises and most compelling that "with appropriate training, unemployed people and underused talent pools can achieve high levels of performance in the contact centre industry" (McKinsey \& Co., 2005: 7). Alongside national government, there has been an acknowledgement of the growth and employment potential of the BPO \& O sector by subnational governments for the purpose of leveraging possibilities for local and regional economic development (Rogerson, 2011).

In order to build the competitiveness of South Africa as a business destination for call centre operations national government has introduced a number of interventions. These relate most significantly to incentives to reduce labour costs, and efforts to stimulate human capital upgrading, particularly in poorer communities (DTI, 2013). In particular, much attention surrounds so-termed impact sourcing which affects both the composition of employees in call centres and seeking to restructure in part the existing geographical patterns of call centre operations. Over the past decade there has been a progressive roll out of government support measures to nurture the BPO \& O economy. National government approved a Cabinet memorandum in December 2006 to recommend substantial assistance and support packages which were formulated in partnership with the private sector (through the Business Trust) for the accelerated development of the BPO sector. This business plan was to focus on, inter alia, supporting the effective marketing of South Africa as a competitive business process outsourcing location; expanding and deepening the pool of local skills and internationally competitive talent; improving the quality of the South African BPO \& O offering; strengthening the industry body capable of mobilizing and representing key industry stakeholders; and, creating an enabling environment of incentives and infrastructure to support the sector (DTI, Business Trust \& Business Enabling South Africa, 2009).

A watershed for the sector was the introduction in 2007 of national government's BPO \& O Investment Incentive to support call centres as one of its national priority sectors. This initiative serves to underscore the government's commitment to BPO \& O development in South Africa (DTI, 2005; 2008a, 2008b). The new financial incentives were geared specifically to promote offshoring and to build South Africa as a competitive destination for call centre work. The initial investment incentive package comprised an investment grant between R37 000 and R60 000 per seat and a training support grant towards costs of company-specific training up to maximum amount of R12 000 per agent (DTI, 2008a, 2008b). Importantly, such incentives target only "local and foreign investors establishing projects that aim primarily 
to serve offshore clients" (DTI, 2008a: 2). The key opportunities for building the BPO\& O economy were recognized in terms of capturing the English-speaking market for service provision, entering the market provided by other investment destinations (particularly in Asia) that are seen as being vacated by investors because of low performance quality, and potentially establishing a South African shared service centre to target the country's immediate hinterland, namely subSaharan Africa (DTI, 2013). Overall, it is argued that "the value proposition of South Africa as a key offshoring destination is anchored in its ability to offer English-speaking talent at scale, a robust enabling environment, deep domain skills advantages, significant cost savings and a 'First World' experience for those who set up operations" (DTI, 2013, p. 108).

Table 2: Progress of South Africa's Revised BPO \& O Incentives, 2011/2012

\begin{tabular}{|l|c|}
\hline \multicolumn{1}{|c|}{ Indicator } & $2011 / 2012$ \\
\hline Number of Applications received & 30 \\
\hline Number of Project approvals & 23 \\
\hline Projected investment (R million) & 4092 \\
\hline Incentives approved (R million) & 184 \\
\hline Average incentive per job & R12 192 \\
\hline Projected employment creation & 15149 \\
\hline
\end{tabular}

\section{Source: Unpublished data from DTI}

During 2011 the incentives were escalated by the Department of Trade and Industry (DTI) with an expanded set of subsidies which are planned to continue at least until March 2014. The emphasis is particularly upon reducing the cost of doing business in the country in order to accelerate employment creation. More specifically, the DTI revised the structure of the earlier incentive offering "from being capital expenditure based to one that provides offsets to investors against operational expenditure costs" (DTI, 2013, p. 109). Under the revised incentive scheme effective 1 January 2011 there is a base incentive which is paid for three years on the basis of the actual number of jobs which are created and sustained. In addition, there is a bonus incentive payable at reaching 401 jobs at a call centre and even higher for 801 plus jobs created. In order to be eligible for these incentives organisations must have registered legal entities in South Africa that create at least 50 offshore jobs over a period of three years and are delivering services to clients outside the country. Significantly, the domestic call centre industry, the backbone of the existing industry, is unaffected by these measures. The rationale for the roll out of a revised incentive programme was stated as follows: "to substantially reduce operating costs, strengthening South Africa's positioning as a world class BPS [Business Process Services] destination able to compete strongly with the offerings of key competitor countries" (DTI, 2013, p. 109). The take-up of these new incentives is shown on Table 2 which reveals approved projects with a projected investment value of R4billion and the potential for catalyzing around 15000 jobs.

Beyond financial incentives other support measures have been introduced to support development of call centres for purposes of job creation, and more especially to assist in impact sourcing towards the youth and disadvantaged areas. Under the Monyetla Work Readiness Programme government provides support for each unemployed person who is trained and thereby aims to expand the pool of entry-level employable people (Nelson Hall, 2011). This programme is described as "a dedicated sector-specific, investor-friendly work readiness programme that bridges the divide between unemployment and the opportunity for sustainable employment over an 80-day training period"(DTI, 2013, p.110). Since the programme's inception in 2007 a total of 4500 youth have been trained to become eligible for work in the BPO \& 0 economy with at least 70 percent of trainees securing employment in the sector. In terms of South Africa as a competitive international destination for the growing economy of BPO \& O potential constraints are an insufficient pool of middle managers as well as the limited availability of certain industry-specific skills (DTI, 2013, p. 109). For accelerating the growth of higher level personnel in terms of supervisors, team leaders, quality controllers and workforce managers further support for training is offered by national government through the Sector Education and Training Programmes. One estimate is that the new packages of incentives and support for training will bring down the average cost per agent per annum to approximately $\$ 17800$ over the next three years. In international comparative perspective this should enable South Africa to increase cost savings compared to UK onshore delivery to 55 percent and put South Africa within a $5 \%$ to $10 \%$ margin of prices charged out of the Philippines, making South Africa worthy of consideration by organisations that are seeking high customer experience but remain price-sensitive relative to traditional offshore alternatives (Nelson Hall, 2011; Lacity et al., 2012; DTI, 2013). 


\section{The Spatial Challenge}

In terms of achieving the objectives of impact sourcing the location choices of call centre operations across South Africa remains a matter of critical concern. Our research interviews with 42 call centres on factors impacting decision-making concerning location revealed that access to labour rather than actual labour costs was the prime consideration governing location choice. In addition, they confirmed that for the majority of call centre operators, at present government incentives would not be considered a major consideration in making a location decision

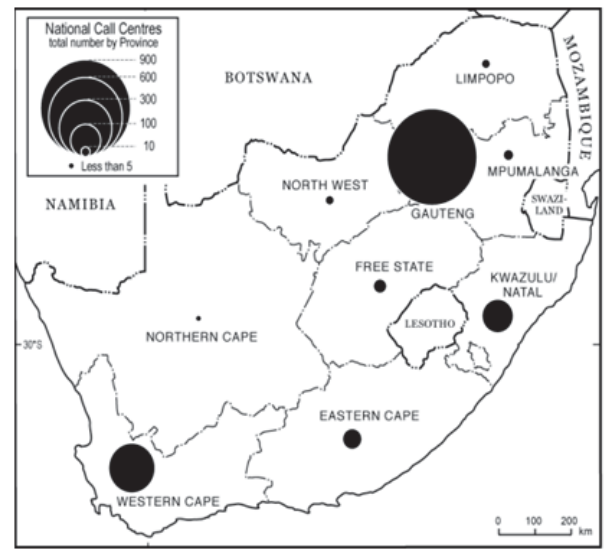

Figure 1: The South African Call Centre Industry, 2012: Provincial Distribution

Figure 1 shows the location of all existing call centres in South Africa mapped on a provincial basis from the national audit that was undertaken. The findings show an uneven geographical distribution with the largest clusters of call centres situated in the country's three most prosperous regions, namely Gauteng, Western Cape and KwaZulu-Natal. By contrast the poorer provinces of Eastern Cape, Free State, North West, Limpopo, Mpumalanga and Northern Cape have relatively few call centres. The existing pattern is therefore of a core-periphery structure with the dominance of the most prosperous regions.

Nationally the largest number of call centres operate from the country's financial capital and economic heart, the city of Johannesburg in Gauteng province. In particular, the city of Johannesburg is the core focus for call centres servicing the domestic market and with in house or captive operations and shows a particular focus on financial services. By contrast the second major centre for the industry is in the Western Cape, and specifically upon Cape Town which is the leading major locus for the delivery of international contact centre services. The third most important province is KwaZulu-Natal and the city of Durban which is increasingly being considered and emerging as a centre linked to areas of technical support. Outside of South Africa's large metropolitan areas the numbers of call centres is relatively thin, despite potential advantages of cheaper labour, estimated to be as much as 30 percent less than Cape Town. Much attention has been given to possibilities associated with new business service parks which have been opened in Polokwane (Limpopo) and Pietermaritzburg (KwaZulu-Natal) to support local development initiatives for building call centre capability. Critical to appreciate is the fact that at the national scale, locational choices are currently not in favour of the most disadvantaged regions of South Africa, which would be the former apartheid-created Bantustans or Homelands, which now constitute the bulk of the country's 23 Priority Development Districts. The potential for impact sourcing is considered better at the intraurban scale with optimism for labour sourcing from unemployed youth in poor township areas of metropolitan South Africa. The actual location choices of call centres is, however, currently weighted towards CBD locations and decentralized commercial nodes especially in Johannesburg and Cape Town.

\section{Conclusion}

This research shows that South Africa is emerging as a competitive location in the growing international economy of Business Process Outsourcing and Offshoring. In the case of call centres the industry evidences signs of maturity from a situation in which virtually all operations were domestic, in house and captive to a wider range of operations, including an 
important segment of offshore operations for international clients. A key driver for the expansion of the call centre industry in South Africa over the past decade has been national government which seeks to lever the sector to address the country's chronic unemployment problems, and more especially the crisis of youth unemployment. With the introduction of new incentives the tempo of the call centre industry greatly improved and is demonstrated by the attraction of major international clients. At the core of growing further the industry in future is the question of human resources and of seeking to utilize impact sourcing to spread further the benefits of new investment in the call centre industry to poorer communities. As has been argued, however, the current patterns of call centres are shaped by locational determinants and a logic that makes the full achievement of government impact sourcing objectives somewhat challenging. At the national inter-urban scale major geographically targeted incentives would be required to restructure the existing pattern of call centre operations which bias towards Johannesburg, Cape Town and Durban. The potential for shifting call centres outside the metropolitan regions into the country's poorest regions is currently limited. More promising, however, are the possibilities for impact sourcing at the intra-urban scale of analysis where with improved intra-urban transportation systems (such as Rea Vaya in Johannesburg) workers can be drawn from poorer areas such as townships for work opportunities in call centres in CBD and decentralized locations. This said, in final analysis certain question marks necessarily must be raised also as whether the targeted pool of young unemployed South Africans have the requisite skills or can be assisted to train to reach the required skill levels for call centre employees (Rogan et al., 2013).

\section{Acknowledgement}

Thanks are due to funding support provided by the National Research Foundation, Pretoria.

\section{References}

Agrawal, S., Goswani, K., \& Chatterjee, B. (2010). The evolution of offshore outsourcing in India. Global Business Review, 11: 239-256. Aziz, M. (2013). Factors causing stress: a study of Indian call centres. Academic Journal of Interdisciplinary Studies, 2 (8): 247-252.

Banks, D. \& Roodt, G. (2011). The efficiency and quality dilemma: what drives South African call centre management performance indicators? SA Journal of Human Resource Management doi10.4102/sajhrm.v9i1.331

Benner, C. (2006). 'South Africa on call': information technology and labour market restructuring in South African call centres. Regional Studies, 40: 1025-1040.

Benner, C., Lewis, C., \& Omar, R. (2007). The South African call centre industry: a study of strategy, human resource practices and performances. Johannesburg: University of Witwatersrand Link Centre.

Bishop, P., Gripaios, P., \& Bristow, G. (2003). Determinants of call centre location: some evidence from UK urban areas. Urban Studies, 40: $2751-2768$.

Bohle, P., Willaby, H., Quinlan, M., \& McNamara, M. (2011). Flexible work in call centres: working hours, work-life conflict and health. Applied Ergonomics, 42 (2): 219-224

C3 Africa Research (2008). National BPO \& call centre report 2007/2008. Sandton: Multimedia Group and C3 Africa Research.

DTI (2005). Business process outsourcing and offshoring: sector development strategy. Pretoria: DTI.

DTI (2008a). BPO\&O Investment Incentive: Programme Guidelines, available at www.thedti.gov.za

DTI (2008b). BPO\&O Investment Incentives: Training Support Grant: Programme Guidelines, available at www.thedti.gov.za

DTI (2013): Industrial Policy Action Plan : Economic Sectors and Employment Cluster - IPAP 2013/14-2015/16. Pretoria: DTI.

DTI, Business Trust, \& Business Process Enabling South Africa (2009). BPO: developing the BPO sector - report to stakeholders 2009. Johannesburg: The Business Trust.

Ee, O., Halim, H.A.,\& Ramayah, T. (2013). The effects of partnership quality on business process outsourcing success in Malaysia: key users perspective. Service Business 7 (2), 227-253.

Ellis, V., \& Taylor, P. (2006). 'You don't know what you've got till it's gone': re-contextualising the origins, development and impact of the call centre. New Technology, Work and Employment, 21: 107-122.

Ghodswar, B., \& Vaidyanathan, J. (2008). Business process outsourcing: an approach to gain access to world-class capabilities. Business Process Management, 14: 23-38.

Ghosh, D. (2013). "Who is grace?: affect, work, and gender in Bangalore call centres. Globalizations, 10 (3): 397-409.

Hannif, Z., Burgess, J., \& Connell, J. (2008). Call centres and the quality of work: towards a research agenda. Journal of Industrial Relations, 50: 271-284.

Hastings, T.M. (2011). A job worth doing?: reinterpreting control, resistance and everyday forms of coping and call centre work in Glasgow. Unpublished Ph D. thesis, University of Glasgow.

Kuruvilla, S. \& Ranganathan, A. (2010). Globalisation and outsourcing: confronting new human resource challenges in India's business process outsourcing industry. Industrial Relations Journal, 41 (2): 136-153.

Lacity, M. \& Willcocks, L.P. (2013). Outsourcing business processes for innovation. MIT Sloan Management Review 54 (3): $63-69$.

Lacity, M., Soloman, S., Yan, A. \& Willcocks, L.P. (2011) Business process outsourcing studies: a critical review and research directions. Journal of Information Technology, 26, 221-258. 
Lacity, M., Willcocks, L. \& Craig, A. (2012), Becoming strategic - South Africa's BPO Service Advantage. London: LSE Outsourcing Unit Working Paper Research Series Paper 12/4, 2012.

Luo, Y. \& Jayaraman, V. (2013). Entry strategies in business process outsourcing. Journal of Leadership and Organizational Studies DOI 10. 1177/1548051812471720.

Marti-Audi, N., Valverde, M. \& Heraty, N. (2013). Human resource management in the Spanish call centre sector: the bird cage model of call centre work. The International Journal of Human Resource Management, 24 (2): 308-329.

McKinsey \& Company (2005). South Africa calling: South Africa's global business process outsourcing \& offshoring opportunity: headline report - June 2005. Report prepared for jointly the City of Johannesburg, The ComMark Trust and The South Africa Foundation.

Mishra, S. (2011). Recasting respectability: habitus, call centres and the modern Indian woman. PhD Dissertation (Sociology), Massey University, Palmerston North, New Zealand.

Mochiko, T. (2013) Call centre sector in push to lure operators. Business Day 11 February

Nelson Hall (2011). Analysis of South Africa as a BPO Delivery Location, 2011. Bracknell, UK: Nelson Hall.

Pandy, W.R \& Rogerson, C.M. (2012). The economic geography of South Africa's call centre industry. Urban Forum 23 (1), $23-42$.

Paulet, R. (2004). Putting call centres in their place. Labour and Industry, 14 (3): 77-89.

Paulet, R. (2008). Location matters: the impact of place on call centres. Journal of Industrial Relations, 50: 305-318.

Penter, K., Pervan, G., \& Wreford, J. (2009). Offshore BPO at large captive operations in India. Information, Technology \& People, 22: 201-222.

Ramesh, B.P. (2004). Cyber coolies in BPO: insecurities and vulnerabilities in non-standard work. Economic and Political Weekly, 39: 492-497.

Richardson, R., \& Bell, V. (2001). Saved by the bell?: call centres and economic development in less favoured regions. Economic and Industrial Democracy, 22: 67-98.

Richardson, R., \& Marshall, J.N. (1996). The growth of telephone call centres in peripheral areas of Britain: evidence from Tyne and Wear. Area, 28: 308-317.

Richardson, R., Belt, V., \& Marshall, N. (2000). Taking calls to Newcastle: the regional implications of the growth of call centres. Regional Studies, 34: 357-369.

Rod, M. \& Ashill, N.J. (2013). The impact of call centre stressors on inbound and outbound call centre agent burnout. Managing Service Quality, 23 (3): 245-264.

Rodolfo, C.S. (2006). Expanding RP-US linkages in business process outsourcing. Makati City: Philippines Institute for Development Studies, Discussion Paper Series No. 2006-10

Rogan, M., Diga, K. and Valodia, I. (2013). Labour Market Analysis and Business Process Services in South Africa: Poverty Reduction through Information and Digital Employment Initiative. Durban: University of KwaZulu-Natal.

Rogerson, C.M. (2011). Tracking local economic development policy and practice in South Africa, 1994-2009. Urban Forum, 22, 149168.

Rowthorn, R. (2010). Combined and uneven development: reflections on the North-South divide. Spatial Economic Analysis, 5: $363-388$.

Sass, M., \& Fifekova, M. (2011). Offshoring and outsourcing business services to Central and Eastern Europe: some empirical and conceptual considerations. European Planning Studies, 19: 1593-1609.

Suchet, K. (2012) Call centres in India: a globalization boon or bane?. International Journal of Research in Social Science, 2 (2): $323-$ 337.

Taylor, P., \& Bain, P. (1999). "An assembly line in the head": work and employee relations in the call centre. Industrial Relations Journal, 30: 101-117.

Taylor, P., \& Bain, P. (2001). Trade unions, worker rights and the frontier of control in UK call centres. Economic and Industrial Democracy, 22: 39-66.

Taylor, P., \& Bain, P. (2005). 'India calling to the far away towns': the call centre labour process and globalization. Work, Employment and Society, 19: 261-282.

Taylor, P., D'Cruz, P., Noronha, E., \& Scholarios, D. (2009). Indian call centres and business process outsourcing: a study in union formation. New Technology, Work and Employment, 24: 19-42.

Taylor, P., D'Cruz, P., Noronha, E., \& Scholarios, D. (2013). The experience of work in India's domestic call centre industry. The International Journal of Human Resource Management, 24 (2): 436-452.

Thaly, P. \& Sinha, V. (2013). To prevent attrition in business process outsourcing, focus on people. Global Business and Organizational Excellence, 32 (3), 35-43.

Vaidyanathan, B. (2012). Professionalism 'from below': mobilization potential in Indian call centres. Work, Employment \& Society, 26 (2): 211-227.

Vincent, R., \& McKeown, L. (2008). Trends in the telephone call centre industry. Ottawa: Statistics Canada.

Vira, B., \& James, A. (2011). Researching hybrid 'economic'/'development' geographies in practice: methodological reflections from a collaborative project on India's new service economy. Progress in Human Geography, 35: 627-651.

Waema, T.M., Odera, G., Adeya-Weya, C.N.A., Were, P., Masinde, E.M., Chepken, C., Kariuki, E., \& Kenduiywo, P. (2009). Development of a business process outsourcing industry in Kenya: critical success factors. Policy brief submitted to the International Development Research Centre, Ottawa IDRC Grant No. 104488-001. 